\title{
A CHECKLIST OF THE NON-ACARINE ARACHNIDS (CHELICERATA: Arachnida) of the De Hoop Nature Reserve, Western Cape Province, South Africa
}

Authors:

Charles R. Haddad ${ }^{1}$

Ansie S. Dippenaar-

Schoeman $^{2}$

\section{Affiliations:}

${ }^{1}$ Department of Zoology \& Entomology University of the Free State,

South Africa

${ }^{2}$ Biosystematics:

Arachnology

ARC - Plant Protection

Research Institute

South Africa

${ }^{2}$ Department of Zoology \& Entomology

University of Pretoria

South Africa

Correspondence to: Charles R. Haddad

e-mail:

haddadcr.sci@ufs.ac.za

\section{Postal address:}

Department of Zoology \& Entomology, University of the Free State, P. O. Box 339, Bloemfontein, 9300, South Africa

Keywords:

De Hoop Nature Reserve; Fynbos Biome; Nonacarine arachnids; species; South African National Survey of Arachnida

\section{Dates:}

Received: 13 Nov. 2007

Accepted: 08 July 2008

Published: 21 Apr. 2009

How to cite this article:

Haddad, C.R. \&

Dippenaar-Schoeman,

A.S., 2009, 'A checklist of

the non-acarine arachnids

(Chelicerata: Arachnida)

of the De Hoop Nature

Reserve, Western Cape

Province, South Africa',

Koedoe 51(1), Art. \#149,

9 page. DOI: $10.4102 /$

koedoe.v51i1.149

This article is available at:

http://www.koedoe.co.za

(C) 2009. The Authors.

Licensee: OpenJournals

Publishing. This work

is licensed under the

Creative Commons

Attribution License.

\section{ABSTRACT}

As part of the South African National Survey of Arachnida (SANSA) in conserved areas, arachnids were collected in the De Hoop Nature Reserve in the Western Cape Province, South Africa. The survey was carried out between 1999 and 2007, and consisted of five intensive surveys between two and 12 days in duration. Arachnids were sampled in five broad habitat types, namely fynbos, wetlands, i.e. De Hoop Vlei, Eucalyptus plantations at Potberg and Cupido's Kraal, coastal dunes near Koppie Alleen and the intertidal zone at Koppie Alleen. A total of 274 species representing five orders, 65 families and 191 determined genera were collected, of which spiders (Araneae) were the dominant taxon (252 spp., 174 genera, 53 families). The most species rich families collected were the Salticidae (32 spp.), Thomisidae (26 spp.), Gnaphosidae (21 spp.), Araneidae (18 spp.), Theridiidae (16 spp.) and Corinnidae (15 spp.). Notes are provided on the most commonly collected arachnids in each habitat.

Conservation implications: This study provides valuable baseline data on arachnids conserved in De Hoop Nature Reserve, which can be used for future assessments of habitat transformation, alien invasive species and climate change on arachnid biodiversity.

\section{INTRODUCTION}

The South African National Survey of Arachnida (SANSA) was initiated in 1997 to record the biodiversity of arachnids in South Africa (Dippenaar-Schoeman \& Craemer 2000). As part of this initiative, surveys are underway in various conservancies, agroecosystems, provinces and biomes. So far, only two long-term surveys have been carried out in Western Cape Province conservancies, namely of the spiders of the Karoo National Park, falling within the Nama Karoo biome (Dippenaar-Schoeman et al. 1999), and the Swartberg Nature Reserve, falling within the Succulent Karoo biome (Dippenaar-Schoeman et al. 2005). These two surveys indicate a moderately high diversity of spiders in these conservancies, with 116 species (38 families) and 186 species (45 families) recorded from the two reserves, respectively.

The Cape Floristic Region comprises unique vegetation types such as fynbos, which are characterised by high levels of plant endemism. According to Linder (2005) some 9,000 species can be found in the region in an area of approximately $90,000 \mathrm{~km}^{2}$. Although the factors influencing insect abundance and diversity in this biome have been well studied (e.g. Giliomee 2003; Procheş \& Cowling 2006; Wright \& Samways 1996, 1999), little is known on the diversity of arachnids in the Fynbos Biome. Coetzee et al. (1990) studied the spiders associated with five proteaceous plant species, Visser et al. (1999) studied the arachnids associated with Protea nitida Mill., and Sharratt (2000) included arachnids in their assessment of the conservation status of cave-dwelling arthropods of the Cape Peninsula.

The general lack of information regarding arachnid diversity, as well as that for many other invertebrate groups in the Western Cape Province, is a great hindrance to effective conservation planning. Conservation strategies should not only take into account plants and vertebrates, but also need to recognise the role that invertebrates play in ecosystem functioning. Arachnids, with the exception of some phytophagous and parasitic Acari, form an important group of predatory terrestrial arthropods that feed on a wide variety of prey using a range of capture methods, including webs and active hunting strategies. Arachnids are frequently regarded as suitable candidates for studying ecological processes, as 1) they are diverse and abundant, 2) they can be easily sampled, 3) they are functionally significant in ecosystems as predators, and as food for other predators, and 4) they interact with their abiotic and biotic environment in a manner that reflects ecological change (Churchill 1997). Therefore, arachnids can be used to monitor ecosystem stability and changes over time, making them useful organisms in long-term conservation planning. Since fynbos vegetation, which is largely endemic to the Western Cape Province, is under increasing threat from urbanisation, agriculture, alien invasive species and climate change (e.g. Picker \& Samways 1996; Richardson et al. 1996; McNeely 2001; Midgley et al. 2003; Witt \& Samways 2004), arachnids provide an alternative taxonomic group to monitor changes in this unique vegetation type.

The present paper aims to report on the diversity of arachnids (excluding the Acari) in the De Hoop Nature Reserve (DHNR) in the Western Cape, which consists of large areas of pristine fynbos and protected marine habitats. Apart from its value as a biodiversity and conservation tool, this checklist can thus be used as a baseline to assess impacts of the aforementioned effects on biodiversity in areas surrounding the reserve. This study forms part of the South African National Survey of Arachnida in conserved areas and the Fynbos Biome, and also contributes towards the checklists of species of the Western Cape Province.

\section{STUDY AREA}

DHNR is situated on the south coast of the Western Cape Province, South Africa, and covers an area of 


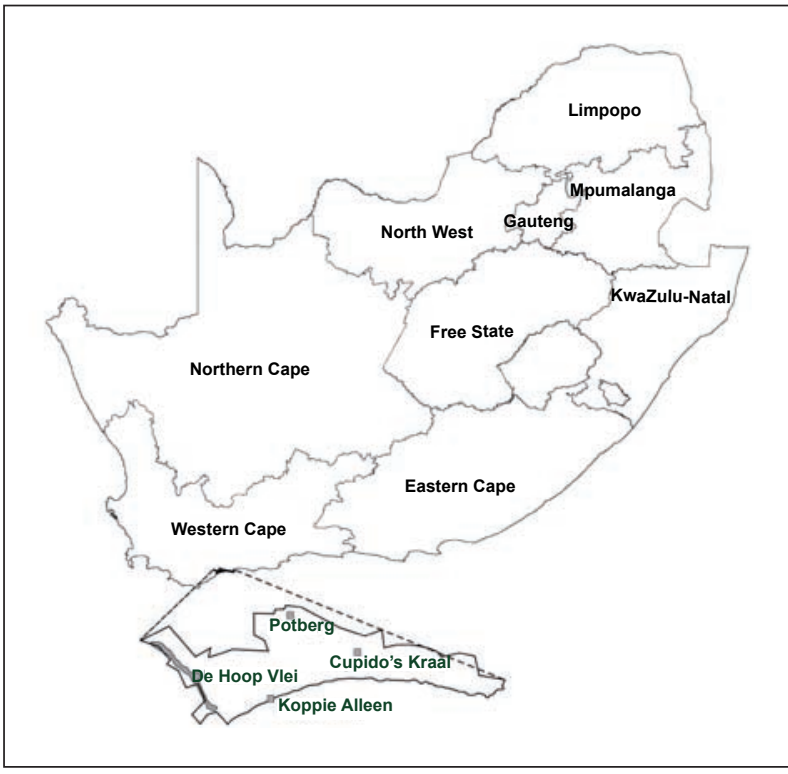

FIGURE 1

Location of the De Hoop Nature Reserve along the South Coast of South Africa. Enlarged map shows key sampling points in the reserve

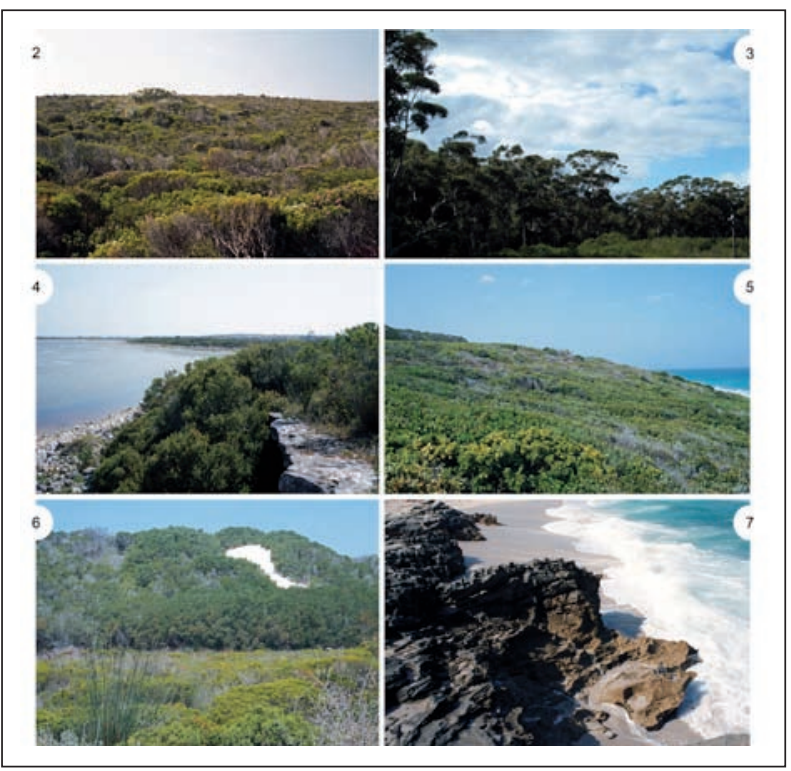

FIGURES 2-7

Habitats sampled in the De Hoop Nature Reserve: 2) Fynbos (FB); 3) Eucalyptus plantation at Potberg (EP); 4) Wetland at De Hoop Vlei (WL); 5-6) Coastal dunes at Koppie Alleen (CD), with natural vegetation (5) and dunes covered with invasive alien Acacia species (6); 7) Intertidal zone at Koppie Alleen (IZ)

32,279 hectares terrestrially (Figure 1). In addition, the coastline and adjacent marine areas are also included in the reserve for the protection of the marine environment and its diversity. For the purposes of this survey the reserve was divided into five broad sampling habitats (plant classification follows Germishuizen et al. 2006):

1. Fynbos (FB) - the largest portion of the reserve contains typical fynbos vegetation characteristic of this particular floral biome (Figure 2). An upper vegetative layer consisting primarily of taller Protea spp. (P. aurea potbergensis Rourke, P. obtusifolia H.Buek ex Meisn. and P. repens (L.) L.) is found in certain areas, particularly near hills and mountains. The field layer comprises a high diversity of fynbos plants, including Agathosma spp., Cliffortia spp., Leucodendron spp., Phylica spp., Serruria fasciflora Salisb. ex Knight and Thamnochortus spp..
2. Eucalyptus plantation (EP) - two large plantations at Potberg and Cupido's Kraal consist primarily of Eucalyptus camaldulensis Dehnh., with endemic low-growing shrubs (e.g. Carissa bispinosa (L.) Desf. ex Brenan) and other short vegetation (Agaranthus sp., Asparagus falcatus L., Bidens sp., Cynodon dactylon (L.) Pers. and Sansevieria hyacinthoides (L.) Druce) (Figure 3).

3. Wetlands $(W L)-$ a single inland wetland, i.e. the De Hoop Vlei, is situated in the south-west of the reserve (Figure 4). The wetland is separated from the ocean by coastal dunes, and therefore does not form a lagoon per se. The De Hoop Vlei is fed by water from the Zout River, the catchment of which receives most of its rainfall during the winter rainfall season. The shores of the wetland are dominated by Sarcocornia spp. and Exomis microphylla (Thunb.) Aellen., with scattered patches of the reed Phragmites australis (Cav.) Steud.. Beyond the shoreline the dominant vegetation includes Sideroxylon inerme $\mathrm{L}$. trees and a variety of fynbos species.

4. Coastal dunes $(C D)$ - coastal dune vegetation is found along the entire coastline of the reserve (Figure 5). Seafacing dunes consist primarily of endemic shrub species, including Carissa bispinosa, Cynanchum obtusifolium L.f., Euclea racemosa Murray, Passerina rigida Wikstr., Ptaeroxylon spp., Robsonodendon sp., Rhus glauca Thunb. and Secamone spp., interspersed with shorter species such as Arctotheca populifolia (P.J.Bergius) Norl., Asparagus falcatus, Bassia diffusa (Thunb.) Kuntze, Chironia baccifera L., Dasispermum suffruticosum (P.J.Bergius) B.L.Burtt, Gazania krebsiana Less., Limonium scabrum (Thunb.) Kuntze, Plantago crassifolia Forssk., Silene primuliflora Eckl. \& Zeyh., Spirobolus sp., Trachyandra ciliata (L.f) Kunth and fynbos vegetation. Many dunes are strongly overgrown with invasive alien plant species such as Acacia cyclops A.Cunn ex G.Don and A. saligna (Labill.) H.L.Wendl. (Figure 6), occasionally interspersed with fynbos elements.

5. Intertidal zone (IZ) - this habitat includes all rocky shores along the coastline and the vegetation immediately associated with the high tide breaker line (Figure 7). On the rocky shores themselves, various marine algae dominate, while plants associated with the high tide mark include scattered fynbos insertions and coastal dune shrubs.

\section{SAMPLING PERIOD AND METHODS}

Intensive sampling for arachnids was carried out during five visits to the reserve. Three of the trips were carried out during early autumn (March 1999 - April 1999, 2004 and 2005) and lasted $10-12$ days each, the fourth trip was undertaken during the middle of winter (July 2005) and lasted four days, and the last trip took place in spring (September 2007) for two days.

Sampling was undertaken ad hoc in each of the habitats by active searching under rocks, logs and in leaf litter, beating foliage, sifting leaf litter and sweeping low-growing vegetation. Additional sampling was conducted by searching under bark in the EP, as this was the only habitat in which loose bark was available. Material was preserved in $70 \%$ ethanol for sorting and identification. Due to time and logistical constraints during the sampling trips, material was not collected quantitatively (i.e. according to a set sampling protocol). Thus, the sampling intensity varied considerably between habitats with a bias towards collecting in $\mathrm{FB}$ and $\mathrm{EP}$, as these were the easiest habitats to access. However, adequate sampling was conducted in the other three habitats using various methods to give a good indication of the arachnid diversity of each.

\section{Guilds observed}

All arachnids were grouped into guilds based on the typical habits known for each family or genus, but also took into consideration the strata in which each species was sampled. 
All arachnid orders collected, with the exception of spiders, can be classified as wanderers. Spiders can be separated into wandering and web-building guilds. The wandering arachnids can be broadly separated into ground wanderers (GW) and plant wanderers $(\mathrm{PW})$. For the latter group, distinction was made between spiders associated with foliage (PWF) of plants and those associated with the bark of trees (PWB). Webbuilding spiders can be separated into various guilds based on the types of webs they construct, namely orb-web builders (OWB), funnel-web builders (FWB), sheet-web builders (SWB), space-web builders (SpWB), hackle-web builders (HWB) and gum-foot-web builders (GWB)

Representative specimens of each species are deposited in the institutions of the various specialists listed in the Acknowledgements, who provided identifications for their respective groups. Material of all the remaining taxa is deposited in the National Collection of Arachnida at the Plant Protection Research Institute, Pretoria, South Africa.

\section{RESULTS \& DISCUSSION}

\section{Diversity}

A total of 274 species of arachnids were collected in DHNR, representing five orders, 65 families and 191 determined genera (Table 1, Appendix 1). The most species rich order was the Araneae, with 252 species in 54 families. This includes one published record of a species that was not collected in the current survey, Nephila fenestrata Thorell (Nephilidae) (Fromhage et al. 2007). The spider family diversity represents the highest from South Africa, exceeding the 46 families collected in the Western Soutpansberg in Limpopo Province (Foord et al. 2002) and Ndumo Game Reserve in KwaZulu-Natal (Haddad et al. 2006). The relatively high spider diversity from fynbos is impressive when compared to more structurally complex habitats such as savanna, where greater species diversity could be expected (see Table 2).

The remaining arachnid orders were relatively poorly represented, the most species rich being the Pseudoscorpiones (nine species, five families), followed by Opiliones (eight species,

TABLE 1

Order composition of the non-acarine arachnids of the De Hoop Nature Reserve, Western Cape Province, South Africa

\begin{tabular}{llrrr}
\hline ORDER & COMMON NAME & FAMILIES & GENERA & SPECIES \\
\hline Araneae & Spiders & 53 & 174 & 252 \\
Opiliones & Harvestmen & 3 & 5 & 8 \\
Pseudoscorpiones & False scorpions & 5 & 7 & 9 \\
Scorpiones & Scorpions & 3 & 4 & 4 \\
Solifugae & Sun spiders & 1 & 1 & 1 \\
\hline Total & & $\mathbf{6 5}$ & $\mathbf{1 9 1}$ & $\mathbf{2 7 4}$ \\
\hline
\end{tabular}

three families), Scorpiones (four species, three families), and Solifugae (one species, one family). One published record of Scorpiones, of Parabuthus planicauda (Pocock) (Buthidae), was found in the literature (Prendini 2004)

As in several other South Africa surveys, Salticidae were the most species rich family (32 spp., $12.7 \%$ of spiders), followed by the Thomisidae (26 spp., 10.3\%) and Gnaphosidae (21 spp., 8.3\%). Several other families contributed $5 \%$ or more of the spider species: Araneidae (18 spp., 7.1\%), Theridiidae (16 spp., $6.3 \%$ ) and Corinnidae (15 spp., 6.0\%). In contrast to some other reserves previously sampled in South Africa, such as the Ndumo Game Reserve in KwaZulu-Natal, the family composition of spiders was considerably less skewed in the current study (Figure 8). At Ndumo, the five dominant spider families contributed $52 \%$ of the species, with the Salticidae dominant (82 spp., 19.0\%) (Haddad et al. 2006). In contrast, the five families dominating the current study contributed $44.7 \%$ of the total spiders, with the dominant Salticidae only contributing $12.7 \%$ of the total

\section{Guilds}

The majority of the arachnid species collected in DHNR are wanderers $(73.0 \%)$, while web-builders comprise $27.0 \%$. When spiders alone are considered, $70.6 \%$ are wanderers while $29.4 \%$ are web-builders. This compares well with several surveys completed in South Africa (Table 2). This indicates that fynbos and associated habitats sampled in this study are sufficiently heterogeneous to support a fauna similar to that found in more structurally complex habitat types, such as savanna.

\section{Common taxa by stratum}

This study was qualitative in its entirety and thus there is no data available on the relative abundance of arachnids. However, based on the frequency of collection and observations made during the study the following species can be recognised as representative of each stratum and guild:

Ground wanderers: A large proportion of the species collected are wandering arachnids on the soil surface (Appendix 1). The coastal dune (CD) fauna was largely dominated by Pardosa and Trabea spp. (Lycosidae), Griswoldia robusta (Simon) (Zoropsidae), Opopaea speciosa (Lawrence) (Oonopidae), Zelotes anchora Tucker (Gnaphosidae), Natta spp. (Salticidae), Diores simoni O. P.-Cambridge (Zodariidae) and Orthobula infima Simon (Corinnidae).

In the Eucalyptus plantation (EP), various gnaphosids (especially Zelotes, Camillina and Xerophaeus spp.), Caponia capensis Purcell (Caponiidae), Opopaea speciosa, Xysticus lucifugus Lawrence (Thomisidae), Griswoldia robusta and Phanotea digitata Griswold (Zoropsidae), Lepthercus rattrayi Hewitt (Nemesiidae), various lycosids, Fuchiba and Fuchibotulus spp. (Corinnidae) and Drassodella vasivulva Tucker (Gallieniellidae) were common.

TABLE 2

Guild composition of spiders collected in the De Hoop Nature Reserve, compared to other surveys carried out in South African conservation areas. Abbreviations: WA wanderers; WB - web-builders

\begin{tabular}{llrrll}
\hline CONSERVANCY & BIOME & SPP. & \%WA & \%WB & REFERENCE \\
\hline De Hoop Nature Res. & Fynbos & 252 & 70.6 & 29.4 & Current study \\
Karoo Nat. Park & Nama Karoo & 116 & 66.4 & 33.6 & Dippenaar-Schoeman et al. (1999) \\
Kruger Nat. Park & Savanna & 152 & 79.0 & 21.0 & Dippenaar-Schoeman \& Leroy (2003) \\
Makalali Game Res. & Savanna & 268 & 69.4 & 30.6 & Whitmore et al. (2002) \\
Mountain Zebra Nat. Park & Nama Karoo & 76 & 53.9 & 46.1 & Dippenaar-Schoeman (2006) \\
Ndumo Game Res. & Savanna & 431 & 74.2 & 25.8 & Haddad et al. (2006) \\
Polokwane Nature Res. & Savanna & 275 & 69.5 & 30.5 & Dippenaar et al. (2008) \\
Roodeplaat Dam Nature Res. & Savanna & 110 & 65.5 & 34.5 & Dippenaar-Schoeman et al. (1989) \\
Sovenga Hill & Savanna & 76 & 83.9 & 16.1 & Modiba et al. (2005) \\
Swartberg Nature Res. & Succulent Karoo & 186 & 76.5 & 23.5 & Dippenaar-Schoeman et al. (2005) \\
Western Soutpansberg & Savanna & 127 & 63.8 & 36.2 & Foord et al. (2002) \\
\hline
\end{tabular}


Opistacanthus capensis Thorell (Liochelidae) and Uroplectes lineatus (C. L. Koch) (Buthidae) were often collected under logs and rocks.

The fynbos (FB) fauna was dominated primarily by lycosids (particularly Pardosa, Trabea and Zenonina spp.), Drassodella vasivulva, various gnaphosids (Camillina, Xerophaeus and Zelotes spp.), Philodromus guineensis Millot and Suemus punctatus Lawrence (Philodromidae) and Afrilobus sp. (Orsolobidae). Large numbers of Pseudoscorpiones were collected by sifting leaf litter of Protea spp.

The fauna at De Hoop Vlei (WL) was strongly dominated by gnaphosids (Zelotes and Xerophaeus spp., and Drassodes ereptor Purcell), lycosids (Geolycosa and Pardosa spp.), and Heliophanus spp. (Salticidae). Various gnaphosids, corinnids and pseudoscorpions were common in sifted leaf litter of Sideroxylon inerme (milkwood) trees near to the wetland.

In the intertidal zone (IZ), only two species were particularly common. Amaurobioides africanus Hewitt (Anyphaenidae) was commonly found in retreats constructed in sandstone formations at the back end of the intertidal zone, while Desis formidabilis (O.P.-Cambridge) (Desidae) was occasionally collected from beneath limpet shells and between algae on the rocky shores. These two species are regarded as marine specialists, occurring only in association with the intertidal zone along rocky shores (Lamoral 1968).

Ground web-builders:Web-builders were generally uncommon on the ground surface, but several species can be singled out. In CD leaf litter, Hahnia spp. (Hahniidae) were frequently found in their sheet-webs, while in FB leaf litter, Benoitia ocellata (Pocock) (Agelenidae) and various linyphiids were common. Lamaika sp. and Vidole capensis (Pocock) (Phyxelididae) were frequently collected in leaf litter and under logs in the EP. The most common web-builders in the WL were Steatoda capensis Hann and Euryopis sp. 1 (Theridiidae), while very few web-builders were collected from the ground level in IZ.
Arachnids associated with bark: Due to the vegetative structure of fynbos, very few large shrubs and trees are found in most of the habitats sampled. Only the EP contained Eucalyptus trees that were large enough to sample arachnids from under bark. Common wandering arachnids collected include Clubiona spp. (Clubionidae), Aneplasa sculpturata Tucker, Poecilochroa anomala (Hewitt) and Upognampa aplanita Tucker (Gnaphosidae), Pseudicius spp. and Menemerus bivittatus (Dufour) (Salticidae), Platyoides quinquedentatus Purcell (Trochanteriidae), Cetonana martini (Simon) (Corinnidae) and Uroplectes lineatus (Buthidae). Dominant web-dwelling spiders include Theridion spp. (Theridiidae) and Neoscona subfusca (C.L. Koch) (Araneidae). Interestingly, several specimens of the tree trapdoor spider Moggridgea peringueyi Simon (Migidae) were collected from their silken burrows under bark.

Foliage wanderers: The fauna of $\mathrm{CD}$ was dominated by Massagris regina Wesolowska and Heliophanus sp. (Salticidae) and predominantly immature Palystes superciliosus L. Koch (Sparassidae). Wandering spiders were quite rare in $\mathrm{WL}$, comprising primarily of Heliophanus spp., various philodromids, and ground-dwelling lycosids (particularly Pardosa spp.) that had wandered onto short vegetation.

In EP, various salticids (Massagris regina, Thyene and Heliophanus spp.), Oxyopes and Hamataliwa spp. (Oxyopidae), Synema spp. (Thomisidae), immature Tibellus minor Lessert (Philodromidae) and Clubiona spp. (Clubionidae) were collected from short shrubs and creepers. The FB plant-dwellers were considerably more diverse. The most common species collected include Chariobas spp. (Zodariidae), various thomisids (Tmarus, Thomisus and Misumena spp.), and salticids (Thyene and Menemerus spp.).

Foliage web-dwellers: Web-dwellers in the $\mathrm{CD}$ and FB were particularly dominated by Neoscona and Cyclosa spp. (Araneidae), Theridion spp. and various linyphiids. Several rare species were also collected in the FB and $\mathrm{EP}$, particularly. The only common web-dweller near the

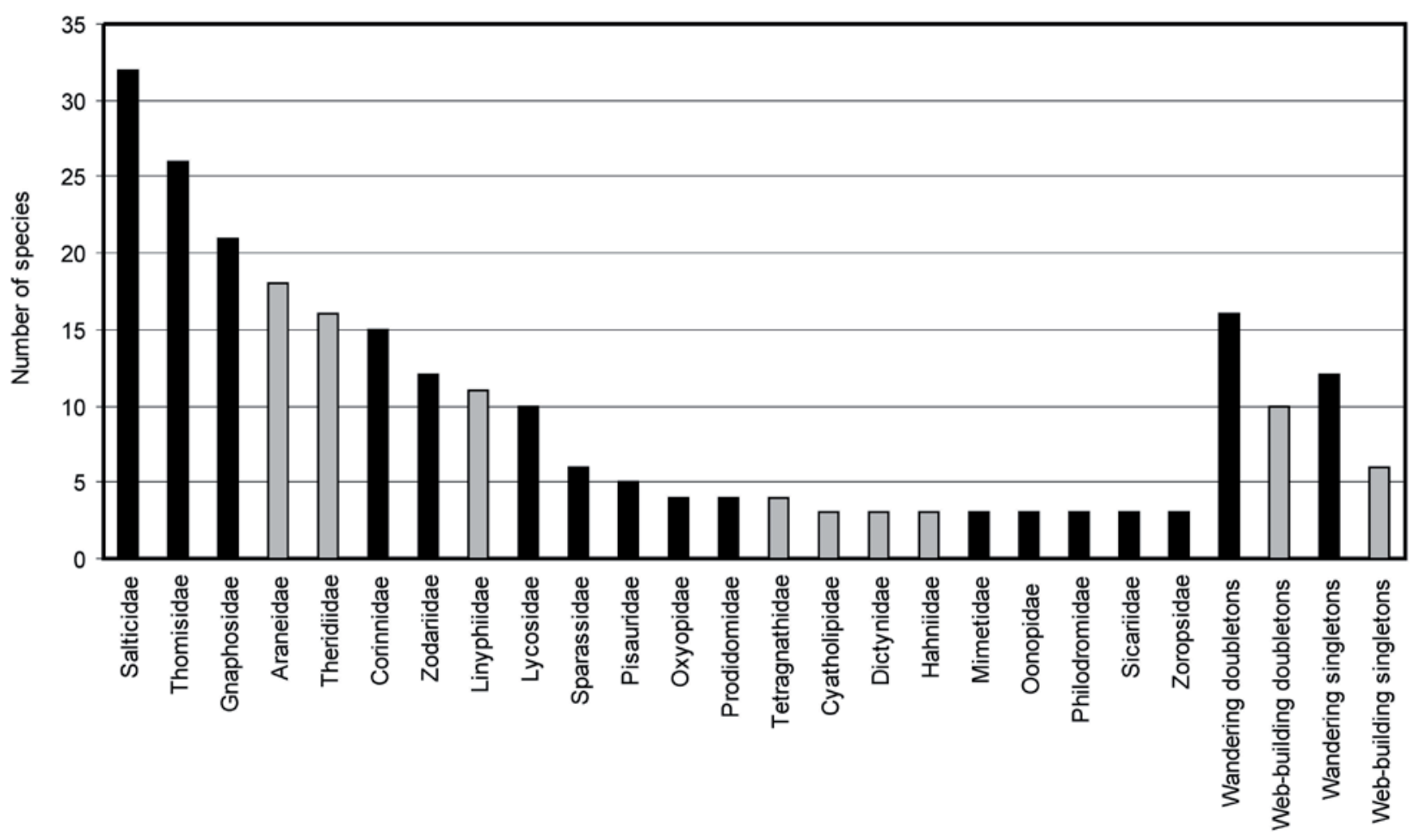

FIGURE 8

Species diversity of spider families collected in the De Hoop Nature Reserve as ranked from highest to lowest. Black bars indicate wandering spiders and grey bars indicate web-builders 
IZ was Larinia natalensis (Grasshoff) (Araneidae), which constructs its orb-web in creepers and other vegetation between rocky outcrops surrounding the intertidal zone.

\section{CONCLUSION}

This study provides the first intensive data on spider diversity in the Fynbos Biome, although two studies have previously been conducted in this vegetation type (Coetzee et al. 1990; Visser et al. 1999). In total, 274 species of arachnids were collected, with spiders the dominant group (252 species). This diversity represents approximately $12.5 \%$ of the currently known South African fauna of approximately 2000 species (DippenaarSchoeman \& Haddad, unpubl.). While the species diversity is slightly lower than surveys conducted in the Savanna Biome, it compares favourably with studies conducted in the Succulent and Nama Karoo Biomes. The relatively high number of arachnid species collected, and the presence of several fynbos endemics (e.g. 10 of the 15 Corinnidae species), supports the generalised perception that fynbos contains a unique fauna and flora.

The only spiders currently considered to be of conservation importance are the baboon spiders, Harpactira cafreriana (Walkenaer) and Harpactirella sp. Both species are relatively common under rocks and within tussocks of Thamnochortis grasses and populations are unlikely to be threatened by occasional collecting. Perhaps also worth noting was the unusual Stasimopes sp. (trapdoor spider), of which only males were collected. These have unusual spine-like tubercles in the eye region, something which could not be traced to any described species in the literature. Consequently, this species may possibly be new or an undescribed male of a described species.

The scorpions collected all have a relatively broad distribution within the Western Cape Province (Prendini pers. comm.). For example, Parabuthus planicauda (Pocock) was recorded from DHNR by Prendini (2004), but is widespread throughout the Western and Eastern Cape Provinces. The occurrence of these scorpions within a protected area such as DHNR can be considered important for the conservation of the species, particularly when the growing threats to the Fynbos Biome are considered.

In this study several new species and three new genera were collected, some of which have recently been described (Haddad 2006; Haddad \& Lyle 2008). This study expanded the distribution ranges known for many species, and provided valuable material for future taxonomic studies. This emphasises the need to expand efforts to survey the arachnid faunas of conservancies throughout South Africa, but particularly within the Western Cape Province, where invertebrate endemism may be relatively high compared to other areas.

\section{ACKNOWLEDGEMENTS}

CapeNature is thanked for permits to collect in the reserve. Peter Chadwick and Keith Spencer at DHNR are thanked for their support and interest in the project. The following taxonomic specialists are thanked for providing identifications of material of their respective taxa: Lorenzo Prendini, American Museum of Natural History, New York, U.S.A. (Scorpiones); Leon Lotz, National Museum, Bloemfontein, South Africa (Miturgidae, Opiliones, Sicariidae); Rudy Jocqué and Mark Alderweireldt, Royal Museum for Central Africa, Tervuren, Belgium (Linyphiidae and Zodariidae, and Lycosidae, respectively); Mark Harvey, Western Australian Museum, Perth, Australia (some Pseudoscorpiones); Wanda Wesołowska, Wrocław University, Wrocław, Poland (Salticidae); and Bernhard Huber, Zoological Institute and Museum Alexander Koenig, Bonn, Germany (Pholcidae). Andor Venter, Johan Venter and Johan du Preez (University of the Free State, Bloemfontein) kindly provided details of the floral composition of the habitats. Several records, collected by Norman Larsen and listed on the
CapeNature invertebrate species database for DHNR, are also acknowledged.

\section{REFERENCES}

Coetzee, J.H., Dippenaar-Schoeman, A.S. \& Van den Berg, A., 1990, 'Spider assemblages on five species of proteaceous plants in the fynbos biome of South Africa', Phytophylactica $22,443-447$.

Churchill, T.B., 1997, 'Spiders as ecological indicators: An overview for Australia', Memoirs of the Museum of Victoria 56(2), 331-337.

Dippenaar, S.M., Modiba, M.A., Khoza, T.T. \& DippenaarSchoeman, A.S., 2008, 'A checklist of the spiders (Arachnida, Araneae) of the Polokwane Nature Reserve, Limpopo Province, South Africa', Koedoe 50, 10-17.

Dippenaar-Schoeman, A.S., 2006, 'New records of 43 spider species from the Mountain Zebra National Park, South Africa (Arachnida: Araneae)', Koedoe 49, 23-28.

Dippenaar-Schoeman, A.S. \& Craemer, C., 2000, 'The South African National Survey of Arachnida', Plant Protection News 56, 11-12.

Dippenaar-Schoeman, A.S. \& Leroy, A., 2003, 'A checklist of the spiders of the Kruger National Park, South Africa (Arachnida: Araneae)', Koedoe, 46, 91-100.

Dippenaar-Schoeman, A.S., Leroy, A, De Jager, M. \& Van den Berg, A., 1999, 'A checklist of the spider fauna of the Karoo National Park, South Africa (Arachnida: Araneae)', Koedoe $42,31-42$.

Dippenaar-Schoeman, A.S., Van den Berg, A.M. \& Van den Berg, A., 1989, 'Species composition and relative seasonal abundance of spiders from the field and tree layers of the Roodeplaat Dam Nature Reserve', Koedoe 32, 25-38.

Dippenaar-Schoeman, A.S., Van der Walt, A.E., De Jager, M., Le Roux, E. \& Van den Berg, A., 2005, 'The spiders of the Swartberg Nature Reserve in South Africa (Arachnida: Araneae)', Koedoe 48, 77-86.

Foord, S.H., Dippenaar-Schoeman, A.S. \& Van der Merwe, M., 2002, 'A checklist of the spider fauna of the Western Soutpansberg, South Africa (Arachnida: Araneae)', Koedoe $45,35-43$.

Fromhage, L., Jacobs, K. \& Schneider, J.M., 2007, 'Monogynous mating behaviour and its ecological basis in the golden orb spider', Nephila fenestrata. Ethology 113(8), 813-820.

Germishuizen, G., Meyer, N.L., Steenkamp, Y. \& Keith, M., 2006, A checklist of South African plants, South African Botanical Diversity Network, Pretoria.

Giliomee, J.H., 2003, 'Insect diversity in the Cape Floristic Region', African Journal of Ecology 41, 237-244.

Haddad, C.R., 2006, 'Spinotrachelas, a new genus of tracheline sac spiders from South Africa (Araneae: Corinnidae)', African Invertebrates 47, 85-93.

Haddad, C.R., Dippenaar-Schoeman, A.S. \& Wesolowska, W., 2006, 'A checklist of the non-acarine arachnids (Chelicerata: Arachnida) of the Ndumo Game Reserve, Maputaland, South Africa', Koedoe 49, 1-22.

Haddad, C.R. \& Lyle, R., 2008, 'Three new genera of tracheline sac spiders from southern Africa (Araneae: Corinnidae)', African Invertebrates 49, 37-76.

Lamoral, B.H., 1968, 'On the ecology and habitat adaptations of two intertidal spiders, Desis formidabilis (OP-Cambridge) and Amaurobioides africanus Hewitt, at The Island (Kommetjie, Cape Peninsula), with notes on the occurrence of two other spiders', Annals of the Natal Museum 20, 151-193.

Linder, H.P., 2005, 'Evolution of diversity: The Cape Flora', Trends in Plant Science 10, 536-541.

McNeely, J., 2001, 'Invasive species: A costly catastrophe for native biodiversity', Land Use and Water Resources Research $1(2), 1-10$.

Midgley, G.F., Hannah, L., Millar, D., Thuiller, W. \& Booth, A., 2003, 'Developing regional and species-level assessments of climatic change impacts on biodiversity in the Cape Floristic Region', Biological Conservation 112(1/2), 87-97. 
Modiba, M.A., Dippenaar, S.M. \& Dippenaar-Schoeman, A.S., 2005, 'A checklist of spiders from Sovenga Hill, an inselberg in the Savanna Biome, Limpopo Province, South Africa (Arachnida: Araneae)', Koedoe 48(2), 109-115.

Picker, M.D. \& Samways, M.J., 1996, 'Faunal diversity and endemicity of the Cape Peninsula, South Africa - a first assessment', Biodiversity and Conservation 5(5), 591-606.

Prendini, L., 2004, 'The systematics of southern African Parabuthus Pocock (Scorpiones, Buthidae): Revisions to the taxonomy and key to the species', Journal of Arachnology 32(1), 109-186.

Procheş, S. \& Cowling, R.M., 2006, 'Insect diversity in Cape fynbos and neighbouring South African vegetation', Global Ecology and Biogeography 15(5), 445-451.

Richardson, D.M., Van Wilgen, B.W., Higgins, S.I., TrinderSmith, T.H., Cowling, R.M. \& Mckell, D.H., 1996, 'Current and future threats to plant biodiversity on the Cape Peninsula, South Africa', Biodiversity and Conservation 5(5), 607-647.

Sharratt, N.J., Picker, M.D. \& Samways, M.J., 2000, 'The invertebrate fauna of the sandstone caves of the Cape Peninsula (South Africa): Patterns of endemism and conservation priorities', Biodiversity and Conservation 9(1), 107-143.

Visser, D., Wright, M.G., Van den Berg, A. \& Giliomee, J.H., 1999, 'Species richness of arachnids associated with Protea nitida (Proteaceae) in the Cape fynbos', African Journal of Ecology, 37(3), 334-343.

Whitmore, C., Slotow, R., Crouch, T.E. \& Dippenaar-Schoeman, A.S., 2002, 'Diversity of spiders (Araneae) in a savanna reserve, Northern Province, South Africa', Journal of Arachnology 30(2), 344-356.

Witt, A.B.R. \& Samways, M.J., 2004, 'Influence of agricultural land transformation and pest management practices on the arthropod diversity of a biodiversity hotspot, and Cape Floristic Region, South Africa', African Entomology 12(1) 89-95.

Wright, M.G. \& Samways, M.J., 1996, 'Gall-insect species richness in African Fynbos and Karoo vegetation: The importance of plant species richness', Biodiversity Letters 3(4/5), 151-155.

Wright, M.G. \& Samways, M.J., 1999, 'Plant characteristics determine insect borer assemblages on Protea species in the Cape Fynbos, and the importance for conservation management', Biodiversity and Conservation 8(8), 1089-1100.

\section{APPENDIX}

A checklist of the non-acarine arachnids of the De Hoop Nature Reserve.

Guild abbreviations are provided in the text. Habitat abbreviations: $\mathrm{CD}$ - coastal dunes; EP - Eucalyptus plantation; FB - fynbos; IZ - intertidal zone; WL - wetlands.

Symbols: $†$ indicates a new species, $\ddagger$ indicates a possible new species, and ? indicates a dubious identification.

\begin{tabular}{lll}
\hline FAMILY/GENUS/SPECIES & GUILDS & HABITATS \\
\hline $\begin{array}{l}\text { ORDER: ARANEAE (SPIDERS) } \\
\text { Family: Agelenidae }\end{array}$ & \\
\hline $\begin{array}{l}\text { Benoitia ocellata (Pocock 1900) } \\
\text { Family: Anapidae }\end{array}$ & FWB & FB \\
\hline $\begin{array}{l}\text { Crozetulus rhodesiensis (Brignoli 1981) } \\
\text { Family: Anyphaenidae }\end{array}$ & OWB & FB \\
\hline Amaurobioides africana (Hewitt 1917) & GW & IZ \\
\hline
\end{tabular}

APPENDIX 1 (CONT...)

\begin{tabular}{|c|c|c|}
\hline FAMILY/GENUS/SPECIES & GUILDS & HABITATS \\
\hline \multicolumn{3}{|l|}{ Family: Araneidae } \\
\hline Araneus apricus (Karsch 1884) & OWB & EP \\
\hline A. nigroquadratus (Lawrence 1937) & OWB & EP \\
\hline Argiope trifasciata (Forskål 1775) & OWB & WL \\
\hline Caerostris sexcuspidata (Fabricius 1793) & OWB & $E P, W L$ \\
\hline Cyclosa insulana (Costa 1834) & OWB & $C D, E P, F B$ \\
\hline C. oculata (Walckenaer 1802) & OWB & FB \\
\hline Cyrtophora citricola (Forskål 1775) & OWB & FB \\
\hline Gea infuscata (Tullgren 1910) & OWB & WL \\
\hline Ideocaira transversa (Simon 1903) & OWB & EP \\
\hline Isoxya cicatricosa (C.L. Koch 1844) & OWB & FB \\
\hline Kilima sp. ${ }^{\ddagger}$ & OWB & WL \\
\hline Larinia natalensis (Grasshoff 1971) & OWB & $\mathrm{FB}, \mathrm{IZ}$ \\
\hline Lipocrea longissima (Simon 1881) & OWB & $\mathrm{FB}, \mathrm{WL}$ \\
\hline Nemoscolus tubicola (Simon 1887) & OWB & WL \\
\hline Neoscona rufipalpis (Lucas 1858) & OWB & WL \\
\hline N. subfusca (C.L. Koch 1837) & OWB & $C D, E P, F B$ \\
\hline Paralarinia bartelsi (Lessert 1933) & OWB & FB \\
\hline Prasonica sp? & OWB & FB \\
\hline \multicolumn{3}{|l|}{ Family: Caponiidae } \\
\hline Caponia capensis (Purcell 1904) & GW/PWB & $\mathrm{CD}, \mathrm{EP}, \mathrm{FB}, \mathrm{WL}$ \\
\hline \multicolumn{3}{|l|}{ Family: Clubionidae } \\
\hline Clubiona abbajensis (Strand 1906) & GW/PWB & $E P, F B, W L$ \\
\hline Clubiona sp. 2 & PWB & $E P, F B$ \\
\hline \multicolumn{3}{|l|}{ Family: Corinnidae } \\
\hline Apochinomma sp. ${ }^{\dagger}$ & GW & FB \\
\hline Castianeira fulvipes (Simon 1896) & GW & $C D, E P, F B$ \\
\hline Cetonana martini (Simon 1896) & GW/PWB & $E P, F B$ \\
\hline Cetonana sp. $2^{\dagger}$ & GW & EP \\
\hline Cetonana sp. $3^{\dagger}$ & GW & FB \\
\hline Cetonana sp. $4^{+}$ & GW & FB \\
\hline Copa flavoplumosa (Simon 1885) & GW & $C D, E P, F B$ \\
\hline Fuchiba capensis (Haddad \& Lyle 2008) & GW & $E P, F B, W L$ \\
\hline Fuchibotulus bicornis (Haddad \& Lyle 2008) & GW & $E P, F B, W L$ \\
\hline Graptartia tropicalis (Haddad 2004) & GW & $C D, E P, F B$ \\
\hline Orthobula infima (Simon 1897) & GW & $\mathrm{CD}, \mathrm{EP}, \mathrm{FB}, \mathrm{WL}$ \\
\hline Pronophaea natalica (Simon 1897) & GW & EP \\
\hline Spinotrachelas capensis (Haddad 2006) & GW & $\mathrm{EP}, \mathrm{FB}, \mathrm{WL}$ \\
\hline Trachelas sp. $1^{\dagger}$ & PWF & FB \\
\hline Trachelas sp. $2^{+}$ & PWF & FB \\
\hline \multicolumn{3}{|l|}{ Family: Ctenidae } \\
\hline Thoriosa sp. ${ }^{\ddagger}$ & GW & $E P, F B$ \\
\hline \multicolumn{3}{|l|}{ Family: Ctenizidae } \\
\hline Stasimopus sp. ${ }^{\ddagger}$ & GW & $E P, F B$ \\
\hline \multicolumn{3}{|l|}{ Family: Cyatholipidae } \\
\hline Cyatholipus quadrimaculatus (Simon 1894) & GWB & EP \\
\hline Cyatholipus sp. $2^{\ddagger}$ & GWB & $E P, F B$ \\
\hline Ulwembua denticulata (Griswold 1987) & OWB & EP \\
\hline \multicolumn{3}{|l|}{ Family: Cyrtaucheniidae } \\
\hline Homostola reticulata (Purcell 1902) & GW & EP \\
\hline \multicolumn{3}{|l|}{ Family: Deinopidae } \\
\hline Avellopsis capensis (Purcell 1904) & MOWB & $E P, F B$ \\
\hline Menneus camelus (Pocock 1902) & MOWB & $E P, F B$ \\
\hline \multicolumn{3}{|l|}{ Family: Desidae } \\
\hline Desis formidabilis (O.P.-Cambridge 1890) & GW & IZ \\
\hline \multicolumn{3}{|l|}{ Family: Dictynidae } \\
\hline Archaeodictyna sp. & HWB & FB \\
\hline Dictyna sp. 1 & HWB & FB \\
\hline Dictyna sp. 2 & HWB & $\mathrm{FB}$ \\
\hline \multicolumn{3}{|l|}{ Family: Eresidae } \\
\hline Dresserus collinus (Pocock 1900) & SWB & $\mathrm{EP}, \mathrm{FB}$ \\
\hline Gandanameno spenceri (Pocock 1900) & SWB & EP, FB \\
\hline
\end{tabular}


APPENDIX 1 (CONT...)

\begin{tabular}{|c|c|c|}
\hline FAMILY/GENUS/SPECIES & GUILDS & HABITATS \\
\hline \multicolumn{3}{|l|}{ Family: Gallieniellidae } \\
\hline Drassodella quinquelabecula (Tucker 1923) & GW & FB \\
\hline D. vasivulva (Tucker 1923) & GW & $\mathrm{CD}, \mathrm{EP}, \mathrm{FB}$ \\
\hline \multicolumn{3}{|l|}{ Family: Gnaphosidae } \\
\hline Aneplasa sculpturata (Tucker 1923) & GW/PWB & $\mathrm{EP}, \mathrm{FB}$ \\
\hline Aphantaulax stationis (Tucker 1923) & GW & $\mathrm{CD}$ \\
\hline Asemesthes sp. imm. & GW & $C D$ \\
\hline Camillina corrugata (Purcell 1907) & GW & $\mathrm{EP}, \mathrm{FB}$ \\
\hline C. pavesii (Simon 1897) & GW & EP, FB, WL \\
\hline C. procurva (Purcell 1908) & GW & $\mathrm{EP}, \mathrm{FB}$ \\
\hline Drassodes ereptor (Purcell 1907) & GW & WL \\
\hline Echeminae sp. indet. & GW & PW \\
\hline Echemus sp. imm. & GW & WL \\
\hline Megamyrmaekion schreineri (Tucker 1923) & GW & WL \\
\hline Micaria sp. & GW & $\mathrm{CD}, \mathrm{FB}$ \\
\hline Poecilochroa anomala (Hewitt 1915) & GW/PWB & $\mathrm{EP}, \mathrm{WL}$ \\
\hline Setaphis subtilis (Simon 1897) & GW & EP \\
\hline Upognampa aplanita (Tucker 1923) & GW/PWB & $E P, W L$ \\
\hline Xerophaeus capensis (Purcell 1907) & GW & FB \\
\hline X. crusculus (Tucker 1923) & GW & $C D, E P, F B, W L$ \\
\hline X. phaseolus (Tucker 1923) & GW & EP, FB \\
\hline Zelotes anchora (Tucker 1923) & GW & $\mathrm{CD}, \mathrm{EP}, \mathrm{FB}, \mathrm{WL}$ \\
\hline Z. capsula (Tucker 1923) & GW & $E P, W L$ \\
\hline Z. fuligineus (Purcell 1907) & GW & $E P, F B, W L$ \\
\hline Z. montanus (Purcell 1907) & GW & $\mathrm{EP}, \mathrm{FB}$ \\
\hline \multicolumn{3}{|l|}{ Family: Hahniidae } \\
\hline Hahnia clathrata (Simon 1898) & SWB & FB \\
\hline H. tabulicola (Simon 1898) & SWB & $C D, E P, F B$ \\
\hline Hahnia sp. $3^{\ddagger}$ & SWB & EP \\
\hline \multicolumn{3}{|l|}{ Family: Idiopidae } \\
\hline Idiopidae sp. & GW & EP \\
\hline \multicolumn{3}{|l|}{ Family: Liocranidae } \\
\hline Rhaeboctesis sp. & GW & FB \\
\hline \multicolumn{3}{|l|}{ Family: Linyphiidae } \\
\hline Callitirchia sp. & SWB & $\mathrm{CD}, \mathrm{FB}$ \\
\hline Ceratinopsis dippenaari (Jocqué, 1984?) & SWB & $\mathrm{CD}, \mathrm{FB}$ \\
\hline Linyphiidae sp. 1 & SWB & FB \\
\hline Linyphiidae sp. 2 & SWB & $\mathrm{FB}$ \\
\hline Linyphiidae sp. 3 & SWB & FB \\
\hline Linyphiidae sp. 4 & SWB & $\mathrm{FB}$ \\
\hline Mecynidis sp..$^{\dagger}$ & SWB & FB \\
\hline Meioneta sp. & SWB & FB \\
\hline Metaleptyphantes sp. & SWB & FB \\
\hline Microlinyphia sterilis (Pavesi 1883) & SWB & EP, FB \\
\hline $\begin{array}{l}\text { Ostearius melanopygius (O.P.-Cambridge } \\
\text { 1879) }\end{array}$ & SWB & WL \\
\hline \multicolumn{3}{|l|}{ Family: Lycosidae } \\
\hline Arctosa sp. & GW & $\mathrm{CD}$ \\
\hline Hogna sp. & GW & $E P, F B, W L$ \\
\hline Lycosa sp. & GW & EP \\
\hline Pardosa sp. 1 & GW & $\mathrm{CD}$ \\
\hline Pardosa sp. 2 & GW & $C D$ \\
\hline Proevippa albiventris (Simon 1898) & GW & WL \\
\hline Trabea purcelli (Roewer 1951) & GW & $\mathrm{CD}, \mathrm{WL}$ \\
\hline T. rubriceps (Lawrence 1952) & GW & $E P, F B, W L$ \\
\hline Trochosa sp? & GW & WL \\
\hline Zenonina sp. & GW & EP, FB, WL \\
\hline \multicolumn{3}{|l|}{ Family: Migidae } \\
\hline Moggridgea peringueyi (Simon 1903) & PWB & EP \\
\hline \multicolumn{3}{|l|}{ Family: Mimetidae } \\
\hline Ero sp. & PWF & EP \\
\hline Mimetus sp. $1^{\ddagger}$ & PWF & EP \\
\hline Mimetus sp. $2^{\ddagger}$ & PWF & WL \\
\hline
\end{tabular}

APPENDIX 1 (CONT...)

\begin{tabular}{|c|c|c|}
\hline FAMILY/GENUS/SPECIES & GUILDS & HABITATS \\
\hline \multicolumn{3}{|l|}{ Family: Miturgidae } \\
\hline Cheiramiona ansiae (Lotz 2002) & PWF & FB \\
\hline \multicolumn{3}{|l|}{ Family: Nemesiidae } \\
\hline Lepthercus rattrayi (Hewitt 1917) & GW & $\mathrm{CD}, \mathrm{EP}, \mathrm{FB}, \mathrm{WL}$ \\
\hline Pionothele sp. $^{\dagger}$ & GW & EP \\
\hline \multicolumn{3}{|l|}{ Family: Nephilidae } \\
\hline Nephila fenestrata (Thorell 1859) & OWB & FB \\
\hline \multicolumn{3}{|l|}{ Family: Oecobiidae } \\
\hline Oecobius navus (Blackwall 1859) & PWB & $C D, F B$ \\
\hline \multicolumn{3}{|l|}{ Family: Oonopidae } \\
\hline Gamasomorpha humicola (Lawrence 1947) & GW & FB \\
\hline Oonopinae sp. & GW & $\mathrm{EP}, \mathrm{FB}$ \\
\hline Opopaea speciosa (Lawrence 1952) & GW & $\mathrm{CD}, \mathrm{EP}, \mathrm{FB}, \mathrm{WL}$ \\
\hline \multicolumn{3}{|l|}{ Family: Orsolobidae } \\
\hline Afrilobus sp. ${ }^{\dagger}$ & GW & $\mathrm{CD}, \mathrm{EP}, \mathrm{FB}$ \\
\hline \multicolumn{3}{|l|}{ Family: Oxyopidae } \\
\hline Hamataliwa kulczynski (Lessert 1915) & PWF & EP, FB \\
\hline Hamataliwa sp. 2 & PWF & EP, FB \\
\hline Oxyopes russoi (Caporiacco 1940?) & PWF & EP \\
\hline Oxyopes sp. $2 \mathrm{imm}$. & PWF & EP \\
\hline \multicolumn{3}{|l|}{ Family: Palpimanidae } \\
\hline Palpimanus sp. 1 & GW & EP, FB, WL \\
\hline Palpimanus sp. 2 & GW & EP \\
\hline \multicolumn{3}{|l|}{ Family: Philodromidae } \\
\hline Philodromus guineensis (Millot 1941) & GW & FB \\
\hline Suemus punctatus (Lawrence 1938) & GW & $\mathrm{CD}, \mathrm{EP}, \mathrm{FB}, \mathrm{WL}$ \\
\hline Tibellus minor (Lessert 1919) & PWF & $\mathrm{EP}, \mathrm{FB}$ \\
\hline \multicolumn{3}{|l|}{ Family: Pholcidae } \\
\hline Quamtana sp. & SpWB & $\mathrm{CD}, \mathrm{FB}$ \\
\hline Smeringopus sp. & SpWB & $\mathrm{EP}, \mathrm{FB}$ \\
\hline \multicolumn{3}{|l|}{ Family: Phyxelididae } \\
\hline Lamaika sp. $^{\dagger}$ & HWB & EP, FB \\
\hline Vidole capensis (Pocock 1900) & HWB & EP, FB \\
\hline \multicolumn{3}{|l|}{ Family: Pisauridae } \\
\hline Chiasmopes sp. imm. & PWF & FB \\
\hline Cispius sp. & PWF & FB \\
\hline Euprosthenopsis sp. imm. & PWF & FB \\
\hline Rothus purpurissatus (Simon 1898) & PWF & $E P, F B$ \\
\hline Thallassius spinossissimus (Karsch 1879) & GW & WL \\
\hline \multicolumn{3}{|l|}{ Family: Prodidomidae } \\
\hline Prodidomus capensis (Purcell 1904) & GW & FB \\
\hline Theuma ababensis (Tucker 1923) & GW & EP \\
\hline T. capensis (Purcell 1907) & GW & FB \\
\hline T. schreineri (Purcell 1907?) & GW & FB \\
\hline \multicolumn{3}{|l|}{ Family: Salticidae } \\
\hline Asemonea sp. & PWF & EP \\
\hline Baryphas ahenus (Simon, 1902) & PWF & FB \\
\hline $\begin{array}{l}\text { Dendryphantes purcelli (Peckham \& Peckham } \\
\text { 1903) }\end{array}$ & PWF & EP \\
\hline Euophrys purcelli (Peckham \& Peckham 1903) & GW & FB \\
\hline Euophrys sp. $2^{\ddagger}$ & GW & EP, FB \\
\hline Evarcha dotata (Peckham \& Peckham 1903) & PWF & EP \\
\hline $\begin{array}{l}\text { Habrocestum sapiens (Peckham \& Peckham } \\
\text { 1903) }\end{array}$ & GW & FB \\
\hline Habrocestum sp. 2 & GW & EP \\
\hline Heliophanus claviger (Simon 1901) & PW & FB \\
\hline H. modicus (Peckham \& Peckham 1903) & GW & $\mathrm{EP}, \mathrm{FB}, \mathrm{WL}$ \\
\hline H. patellaris (Simon 1901) & GW & WL \\
\hline Heliophanus sp. 4 & GW/PWF & $C D, I Z$ \\
\hline Massagris regina (Wesolowska 1993) & GW & $\begin{array}{l}\mathrm{CD}, \mathrm{EP}, \mathrm{FB} \\
\mathrm{IZ}, \mathrm{WL}\end{array}$ \\
\hline Menemerus bivittatus (Dufour 1831) & PWB & EP \\
\hline Menemerus sp. 2 & PWF & FB \\
\hline Myrmarachne leleupi (Wanless 1978) & GW & $C D, F B$ \\
\hline Myrmarachne sp. 2 & GW & FB \\
\hline
\end{tabular}


APPENDIX 1 (CONT...)

\begin{tabular}{|c|c|c|}
\hline FAMILY/GENUS/SPECIES & GUILDS & HABITATS \\
\hline Natta chionogastra (Simon 1901) & GW & EP, FB \\
\hline N. horizontalis (Karsch 1879) & GW & $\mathrm{CD}, \mathrm{EP}, \mathrm{FB}$ \\
\hline Pellenes geniculatus (Simon, 1868)? & GW & $\mathrm{FB}, \mathrm{WL}$ \\
\hline $\begin{array}{l}\text { Phintella aequipes (Peckham \& Peckham } \\
\text { 1903) }\end{array}$ & GW & EP \\
\hline Phlegra sp.? & GW & EP \\
\hline Pignus sp. ${ }^{\ddagger}$ & GW & EP \\
\hline $\begin{array}{l}\text { Pseudicius africanus (Peckham \& Peckham } \\
\text { 1903) }\end{array}$ & PWB & EP \\
\hline Pseudicius sp. 2 & PWF & FB \\
\hline Rhene sp. imm. & PWF & FB \\
\hline Salticidae sp. indet. 1 & PWF & $\mathrm{FB}$ \\
\hline Salticidae sp. indet. 2 & GW & $C D$ \\
\hline Thyene inflata (Gerstaecker 1873) & PWF & $\mathrm{EP}, \mathrm{FB}$ \\
\hline T. ogdeni (Peckham \& Peckham 1903?) & PWF & $\mathrm{EP}, \mathrm{FB}$ \\
\hline Thyene sp. 3 & PWF & FB \\
\hline Thyenula sp? & GW & EP \\
\hline \multicolumn{3}{|l|}{ Family: Scytodidae } \\
\hline Scytodes cedri (Purcell 1904) & GW & $\mathrm{CD}, \mathrm{EP}, \mathrm{FB}, \mathrm{WL}$ \\
\hline Scytodes sp. 2 & GW & EP \\
\hline \multicolumn{3}{|l|}{ Family: Segestriidae } \\
\hline Ariadna sp. & TWB & FB \\
\hline \multicolumn{3}{|l|}{ Family: Selenopidae } \\
\hline Anyphops capensis (Lawrence 1940) & PWB & EP, FB \\
\hline Anyphops sp. 2 & PWB & $E P, F B, W L$ \\
\hline \multicolumn{3}{|l|}{ Family: Sicariidae } \\
\hline Loxosceles spinulosa (Purcell 1904) & GW & EP, FB \\
\hline Loxosceles sp..$^{\ddagger}$ & GW & EP \\
\hline Sicarius spatulatus (Pocock 1901) & GW & EP, FB \\
\hline \multicolumn{3}{|l|}{ Family: Sparassidae } \\
\hline Olios sp. 1 & PWF & FB \\
\hline Olios sp. 2 & PWF & FB \\
\hline Palystes castaneus (Latrielle 1819) & PWF & $\mathrm{EP}, \mathrm{FB}$ \\
\hline P. superciliosus (L. Koch 1875) & PWF & $\mathrm{CD}, \mathrm{EP}, \mathrm{FB}$ \\
\hline Panaretella sp. & PWF & FB \\
\hline Pseudomicrommata sp. & PWF & $\mathrm{FB}$ \\
\hline \multicolumn{3}{|l|}{ Family: Tetragnathidae } \\
\hline Leucauge festiva (Blackwall 1866) & OWB & $E P, F B, W L$ \\
\hline L. levanderi (Kulzcynski 1901) & OWB & EP, FB, WL \\
\hline $\begin{array}{l}\text { Tetragnatha ceylonica (O.P.-Cambridge } \\
\text { 1869) }\end{array}$ & OWB & EP, FB \\
\hline Tetragnatha sp. 2 & OWB & EP \\
\hline \multicolumn{3}{|l|}{ Family: Theraphosidae } \\
\hline Harpactira cafreriana (Walkenaer 1837) & GW & EP, FB \\
\hline Harpactirella sp. & GW & FB \\
\hline \multicolumn{3}{|l|}{ Family: Theridiidae } \\
\hline Achaearanea sp. & GWB & EP \\
\hline Anelosimus sp. 1 & GWB & $\mathrm{FB}$ \\
\hline Anelosimus sp. 2 & GWB & FB \\
\hline Dipoena sp. 1 & GWB & $\mathrm{CD}, \mathrm{EP}, \mathrm{FB}$ \\
\hline Dipoena sp. 2 & GWB & FB \\
\hline Dipoenura sp. & GWB & $\mathrm{FB}$ \\
\hline Euryopis sp. 1 & GWB & $\mathrm{FB}, \mathrm{WL}$ \\
\hline Euryopis sp. 2 & GWB & FB \\
\hline Latrodectus geometricus (C.L. Koch 1841) & GWB & EP, FB \\
\hline L. indistinctus (O.P.-Cambridge 1904) & GWB & EP \\
\hline Pholcomma sp? & GWB & FB \\
\hline Phoroncidia capensis (Simon 1895)? & GWB & EP \\
\hline Steatoda capensis (Hann 1990) & GWB & $E P, F B, I Z$ \\
\hline Theridion delicatum (O.P.-Cambridge 1904) & GWB & EP, FB \\
\hline Theridion sp. 2 & GWB & $\mathrm{EP}, \mathrm{FB}$ \\
\hline Theridion sp. 3 & GWB & $\mathrm{EP}$ \\
\hline \multicolumn{3}{|l|}{ Family: Theridiosomatidae } \\
\hline Theridiosomatidae sp. & OWB & FB \\
\hline
\end{tabular}

APPENDIX 1 (CONT...)

\begin{tabular}{|c|c|c|}
\hline FAMILY/GENUS/SPECIES & GUILDS & HABITATS \\
\hline \multicolumn{3}{|l|}{ Family: Thomisidae } \\
\hline Avelis hystriculus (Simon 1895)? & PWF & EP \\
\hline Diaea sp. ${ }^{\dagger}$ & PWF & $E P, F B$ \\
\hline Firmicus abnormis (Lessert 1923) & PWF & $E P, F B$ \\
\hline F. bragantinus (Brito Capello 1866) & PWF & FB \\
\hline Heterogriffus berlandi (Lessert 1938) & PWF & $E P, F B$ \\
\hline Heterogriffus sp. $2^{\ddagger}$ & PWF & FB \\
\hline $\begin{array}{l}\text { Holopelus almiae (Dippenaar-Schoeman } \\
\text { 1986) }\end{array}$ & PWF & $\mathrm{FB}$ \\
\hline Monaeses pustulosus (Pavesi 1895) & PWF & $\mathrm{FB}$ \\
\hline Oxytate argenteooculata (Simon 1886) & PWF & $E P, F B$ \\
\hline Pactactes obesus (Simon 1895) & GW & $\mathrm{CD}, \mathrm{EP}, \mathrm{FB}, \mathrm{WL}$ \\
\hline $\begin{array}{l}\text { Pherecydes tuberculatus (O.P.-Cambridge } \\
\text { 1883) }\end{array}$ & PWF & FB \\
\hline Pherecydes sp. $2^{\dagger}$ & PWF & $E P, F B$ \\
\hline Phrynarachne melloleitoa (Lessert 1933) & PWF & EP \\
\hline P. rugosa (Latreille 1804) & GW & $\mathrm{EP}$ \\
\hline Runcinia aethiops (Simon 1901) & PWF & $E P, F B$ \\
\hline Simorcus capensis (Simon 1895) & PWF & $\mathrm{FB}$ \\
\hline Stiphropus sp. & GW & $\mathrm{FB}$ \\
\hline Synema abnorme (Lessert 1923) & PWF & $E P, F B$ \\
\hline S. decens (Karsch 1878) & PWF & $E P, F B$ \\
\hline S. nigrotibiale (Lessert 1919) & PWF & $E P, F B$ \\
\hline Thomisus australis (Comellini 1957) & PWF & FB \\
\hline T. stenningi (Pocock 1900) & PWF & $\mathrm{FB}$ \\
\hline Tmarus comellinii (Garcia-Neto 1989) & PWF & $E P, F B$ \\
\hline T. foliatus (Lessert 1928) & PWF & FB \\
\hline Tmarus sp. $3^{\ddagger}$ & PWF & $E P, F B$ \\
\hline Xysticus lucifugus (Lawrence 1937) & GW & $E P, F B$ \\
\hline \multicolumn{3}{|l|}{ Family: Trochanteriidae } \\
\hline Platyoides leppanae (Pocock 1902) & PWB & EP \\
\hline P. quinquedentatus (Purcell 1907) & PWB & $\mathrm{EP}$ \\
\hline \multicolumn{3}{|l|}{ Family: Uloboridae } \\
\hline $\begin{array}{l}\text { Miagrammopes brevicaudus (O.P.-Cambridge } \\
\text { 1882) }\end{array}$ & MOWB & EP \\
\hline Uloborus sp. imm. & OWB & $C D, E P, F B$ \\
\hline \multicolumn{3}{|l|}{ Family: Zodariidae } \\
\hline Caesetius globicoxis (Lawrence 1942) & GW & $E P, F B$ \\
\hline Chariobas cylindraceus (Simon 1893)? & PWF & $E P, F B$ \\
\hline Chariobas sp. $2^{\ddagger}$ & PWF & $\mathrm{FB}$ \\
\hline Chariobas sp. $3^{\ddagger}$ & PWF & $\mathrm{FB}$ \\
\hline Cyrioctea griswoldorum (Platnick \& Jocqué 1993) & GW & $E P, F B$ \\
\hline Diores simoni (O.P.-Cambridge 1904)? & GW & $\mathrm{CD}, \mathrm{FB}, \mathrm{WL}$ \\
\hline Heradida extima (Jocqué 1987) & GW & WL \\
\hline Procydrela procursor (Jocqué 2000) & GW & $\mathrm{FB}$ \\
\hline Psammorygma sp. & GW & FB \\
\hline Ranops sp.? & GW & $C D$ \\
\hline Rotundrela rotunda (Jocqué 2000) & GW & $E P, F B$ \\
\hline Systenoplacis sp..$^{\ddagger}$ & GW & EP, FB \\
\hline \multicolumn{3}{|l|}{ Family: Zoridae } \\
\hline Voraptus sp. & GW/PWF & EP, FB \\
\hline \multicolumn{3}{|l|}{ Family: Zoropsidae } \\
\hline Griswoldia robusta (Simon 1898) & GW & $\begin{array}{l}\text { CD, EP, FB, } \\
\text { IZ, WL }\end{array}$ \\
\hline Machadoniinae sp. & GW & $\mathrm{FB}$ \\
\hline Phanotea digitata (Griswold 1994) & GW & $\mathrm{CD}, \mathrm{EP}, \mathrm{FB}$ \\
\hline \multicolumn{3}{|l|}{ ORDER: OPILIONES (HARVESTMEN) } \\
\hline \multicolumn{3}{|l|}{ Family: Caddidae } \\
\hline Caddella sp..$^{\dagger}$ & GW & $C D$ \\
\hline \multicolumn{3}{|l|}{ Family: Phalangiidae } \\
\hline Rhampsinitus vittatus (Lawrence 1931)? & GW & $\mathrm{CD}, \mathrm{EP}, \mathrm{FB}$ \\
\hline \multicolumn{3}{|l|}{ Family: Triaenonychidae } \\
\hline Adaeum spatulatum (Lawrence 1931) & GW & $\mathrm{EP}, \mathrm{FB}, \mathrm{WL}$ \\
\hline Ceratomontia annae (Lawrence 1934) & GW & $\mathrm{FB}$ \\
\hline C. karooensis (Lawrence 1931) & GW & $\mathrm{FB}, \mathrm{WL}$ \\
\hline C. minor (Lawrence 1931) & GW & $\mathrm{FB}, \mathrm{WL}$ \\
\hline
\end{tabular}


APPENDIX 1 (CONT...)

\begin{tabular}{|c|c|c|}
\hline FAMILY/GENUS/SPECIES & GUILDS & HABITATS \\
\hline Larifuga granulosa (Lawrence 1931) & GW & EP, FB \\
\hline Triaenonychidae sp. imm. & GW & $\mathrm{EP}$ \\
\hline \multicolumn{3}{|c|}{ ORDER: PSEUDOSCORPIONES (FALSE SCORPIONS) } \\
\hline \multicolumn{3}{|l|}{ Family: Atemnidae } \\
\hline Cyclatemnus sp. & GW & IZ \\
\hline \multicolumn{3}{|l|}{ Family: Cheliferidae } \\
\hline Beierius simplex (Beier 1955) & GW & FB \\
\hline B. walliskewi (Ellingsen 1912) & GW & FB \\
\hline Hansenius sp. & GW & $\mathrm{EP}$ \\
\hline \multicolumn{3}{|l|}{ Family: Chernetidae } \\
\hline Caffrowithius biseriatus (Mahnert 1983) & GW & FB \\
\hline C. natalensis (Beier 1947) & GW & FB \\
\hline Pselaphochernes natalensis (Beier 1947) & GW & FB \\
\hline \multicolumn{3}{|l|}{ Family: Geogarypidae } \\
\hline Geogarypus purcelli (Ellingsen 1912) & GW & $E P, I Z$ \\
\hline \multicolumn{3}{|l|}{ Family: Tridenchthoniidae } \\
\hline Anaulacodithella angustimana (Beier 1955) & GW & FB \\
\hline \multicolumn{3}{|l|}{ ORDER: SCORPIONES (SCORPIONS) } \\
\hline \multicolumn{3}{|l|}{ Family: Buthidae } \\
\hline Parabuthus planicauda (Pocock 1889) & GW & $\mathrm{CD}, \mathrm{EP}, \mathrm{FB}$ \\
\hline Uroplectes lineatus (C.L. Koch 1844) & GW/PWB & $E P, F B, W L$ \\
\hline \multicolumn{3}{|l|}{ Family: Liochelidae } \\
\hline Opistacanthus capensis (Thorell 1877) & GW & EP, FB \\
\hline \multicolumn{3}{|l|}{ Family: Scorpionidae } \\
\hline Opistophthalmus macer (Thorell 1877) & GW & EP \\
\hline \multicolumn{3}{|l|}{ ORDER: SOLIFUGAE (SUN-SPIDERS) } \\
\hline \multicolumn{3}{|l|}{ Family: Solpugidae } \\
\hline Solpugema sp. imm. & GW & FB \\
\hline
\end{tabular}

